\title{
TEORI AL-ISTISHLAH DALAM PENERAPAN HUKUM ISLAM
}

\section{Oleh}

\section{Mursyidin Ar-Rahmaniy}

\begin{abstract}
ABSTRAKSI
Konsep Al Istislah ditetapkan menjadi hukum fiqh yang sama dengan Mashalih al Mursalah. Al Mashlahat al Mursalah adalah mashlahat yang dapat menarik manfaat dan menolak kemudharatan. Mashlahat yang didatangkan oleh syari’at Islam adalah untuk merealisasikan mashlahat dalam bentuk yang secara umum, memberikan hukum syara kepada suatu kasus yang tidak terdapat dalam Nash dan Ijma' atas dasar memelihara yang terlepas yaitu kemeslahatan yang tidak ditegaskan oleh syara' dan tidak pula di tolak. Walaupun Nash al Syar'iyat mendatangkan hukum untuk merealisir kemeslahatan. Ruang lingkup Mashalih almurslah adalah setiap kemashlahatan yang masuk kedalam Maqashid al Syar`i (tujuan pembuatan syara`) yang secara garis besarnya ada lima masalah pokok kemeslahatan dalan tujuan al syari`at (Maqashid al Tasyri'). Kelima ini adalah : maqashid li al Dini (tujuan untuk menjaga agam), maqashid li al Nafsi (tujuan untuk menjadan jiwa), maqashid li al Aqli (tujuan untuk menjaga akal), maqashid li al Nasabi (tujuan untuk menjaga keturunan), maqashid li al Mali (tujuan untuk menjaga harta). Hukum Fiqh yang ditetapkan oleh Metode al Istislah adalah mendatangkan kemaslahatan dan menjauhkan kemafsadatan. Walauun para ahli dan para Imam Mujtahid (imam mazhab) memandang al Istislah (bahkan termasuk al Istihsan), memiliki pandangan yang berbeda. Namnu mereka masingmasing memiliki sikap yang jelas dalam melihat istilah ini, baik bersifat positif maupun negatif.
\end{abstract}

Keyword: Al Istishlah, Hukum Islam

\section{PENDAHULUAN}

Syariat Islam datang untuk merealisir kebaikan pada manusia, apabila ditelusuri, maka isi dari pada syariat adalah kemeslahatan dan menghindari dari kemafsadaan. Kemaslahatan di sini adalah kemaslahatan dunia dan akhirat, yang mencakup denan keadilan, ramat dan ni`mat. Semuah unsur kemeslahatn ini tercantum dalam lingkup hukum dengan metode pemahaman fiqh.

Sumber yang digunakan dalam memahami fiqh adalah Alquran, sunnah, Ijma` dan Qiyas serta istinbath para mujtahid dari petunjuk-peunjuk nash dan 
kaedah-kaedah syara`. Oleh karena itu, para ulama menempatkan empat smber fiqh yang terdiri dari Alquran, Sunnah, Ijma` dan Qiyas yang merupakan sumber primer dari syariat Islam.

Selain empat sumber primer tersebut diatas, terdapat sumber-sumber lain yang diamnggap sumber skunder dalam menetapkan hukum syar i. Nash Alquran dan sunah menunjukkan bahwa sandaran-sandaran tersebut dapat diakui sebagai sandaran yang shahih (benar) dalam nenetapkan hukum.

Walupun demikian, sumber-sumber yang lain tersebut merupakan sumber yang merupakan sumber taba`iyah (skunder) yang bersifat furu`iyah. Oleh karena itu, manyoritas ulama tidak menganggap tambahan sumber selain empat sumber di atas. Akan tetapi hanya dianggap sebagai marji (sumberskunder). Jadi dari sember-suber skunder tersebut, yang paling pentin ada tiga yaitu Istihsan, Istishlah atau kaedah mashlahah mursalah dan `Urf (adat kebiasaan).

Dalam hal ini akan dijelaskan secara baik dan detil dalam pembahasan ini secara sistematis dan teratur, namun yang akan dijelaskan secara pokok mengenai al Istshlah atau yang disebutkan dengan mashlahah mursalah.

\section{KONSEP AL ISTISLAH DAN MASHALIH AL MURSALAH.}

Kata Istishlah berasal dari bahasa Arab dengan asal kata Shalaha yang dapat diberikan arti dengan "baik". Kata Al Istishlah artinya adalah :

$$
\text { فإن استصلاح : الهواء من أَعون الأَشياء على صحة الأَبدان }
$$

sebuah keinginan untuk memperbaiki sesuau secara sehat badan. ${ }^{1}$

Al Istislah ini dapat ditetapkan dalam hukum fiqh sama dengan Mashlahah al Mursalah. Ruang lingkup Mashlahah al Mursalah adalah setiap kemashlahatan yang masuk kedalam Maqashid al Syar ${ }^{i}$ (tujuan pembuatan syara`).

Mashlahat al-Mursalah dapat dikatakan adalah mashlahat secara umum, yaitu segala sesuatau yang dapat menarik manfaat dan menolak kemudharatan. Mashlahat yang didatangkan oleh syari at Islam adalah untuk merealisasikan

${ }^{1}$ Al Anshar, Lisan Al Arab, Juz,9, hlm 279. Taj al Urus, juz.1, hlm.6066. Al Nihayat fi al Gharib al Atasr, Juz.4, hlm. 70. 
mashlahat dalam bentuk yang secara umum. ${ }^{2}$ Jadi, al Mashalih al Murshalah adalah memberikan hukum syara` kepada suatu kasus yang tidak terdapat dalam Nash dan Ijma' atas dasar memelihara yang terlepas yaitu kemeslahatan yang tidak ditegaskan oleh syara` dsn tidsk pula di tolak. ${ }^{3}$ Walaupun Nash al Syar`iyat mendatangkan hukum untuk merealisir kemeslahatan. Hal ini terbukti dalam berbagai perisiwa dan kejadian, seperti mengharamkan Khamar, perzinaan, pembunuhan dan lain-lain.

Sebaliknya atau lawan dari pada Mashlahat adalah Mafasadat. Kalau Mashlahat dapat diartikan dengan manfaat, maka Mafsadat ini dapat diartikan dengan madharat. Keduanya adalah dua jenis kata yang saling berlawanan. Namun demikian dari istilah ini dapat dipahami juga, melalui kesulitan dan kepayahan akan menimbulkan hasil yang baik. Seperti pahitnya minum obat, akan membawa hasil yang baik. Demikian juaga mengenai Jihad, akan memudharatkan harta dan jiwa, akan tetapi akan menimbulkan kebaikan bagi generasi berikutnya serta mencapai keamanan dari bahaya musuh.

Kemeslahatan yang didasarkan oleh syari’at secara garis besarnya ada lima masalah pokok kemeslahatan dalan tujuan al syari’at (Maqashid al Tasyri`). Kelima ini adalah : maqashid li al Dini (tujuan untuk menjaga agam), maqashid li al Nafsi (tujuan untuk menjadan jiwa), maqashid li al Aqli (tujuan untuk menjaga akal), maqashid li al Nasabi (tujuan untuk menjaga keturunan), maqashid li al Mali (tujuan untuk menjaga harta).

Dari kelima tujuan tersebut, maka para Ulama membagi mashlahat dalam pandangan syari`at yang sesuai dengan petunjuk nash-nash syari`at dan hukumhukumnya kepada tiga bahagian (tingkatan), yaitu :

1. Al Dharuriyat (kebutuhan pokok/primer), yaitu perkara yang dapat menjaga kelima tujuan pokok syar’i, berupa pekerjaan, aturan, tindakan dan lain-lain, yang sesuai dengan pandangan syara`. Hal ini

${ }^{2}$ Al Zarqa', Mustafa Ahmad, Al Istishlah wa al Mashalih al Mursalah fi al Syariat al Islamiyah wa Ushul Fiqh, Trj. Ade Dedi Rohayana, Hukum Islam dan Perubahan Sosial, (Jakarta: Riora Cipa, 2000), hlm.35.

${ }^{3}$ HA.Djazuli Prof., dan Nurol Aen MA, Drs., Ushul Fiqh, (Bandung Gilang Adiiya Press, 1996), hlm.131 
menjadi tempat tegaknya kehidupan manusia yang sekiranya apabila ditinggalkan, maka terjadilah kemafsadatan dan timbul berbagi fitnah dan kehancuran yang hebat.

2. Al Hajjiyat (kebutuhan skunder), yaitu Perbuatan dan tindakan kalau hal ini tidak ada, maka tidak mengganggu dan tidak sampai rusak. Demikian juga kerusuhan dan kerusakan tidak sampai bertebaran sebagaimana dalam kebutuhan dharuriyat. Perkata-perkara seperti ini adalah yang tetap diperlukan manusia untuk menghilangkan dan menghindarkan dirinya dari kesulitan dan kesempitan, seperti berburu, transaksi sewa-menyewa dan lain-lain.

3. Al Tahsiniyat atau al Kamliyah, al Takmiliyah, (kebutuhan tersier atau kebutuhan pelengkap), yaitu kebutuhan ini apabila ditinggalkan, maka tidak mendesak dan tidak menjadi rusak bagi yang meninggalkan. Al Tahsiniyah ini menyangkut dengan perkaraperkara yang layak dikerjakan demi menjaga harga diri, moral dan akhlak yang mulia seperti etika berbicara, makan-minum dan etika keseharian lainnya, serta kesederhanaan dalam penggunaan harta dan dermawan.

Ketiga tingkatan kebutuhan hukum ini adalah disyari`atkan untuk memeliharakan perkara-perkara yang dharuri (pokok) merupakan hukum yang paling penting dan paling berhak untuk dipeliharakan. Kemudian diikuti oleh hukum-hukum yang disyari atkan untuk melindungi perkara-perkara tersebut yaitu apa yang disebutkan dengan kebutuhan Hajjiyat (skunder). Selanjutnya diikuti oleh kebutuhan Tahsini (kebutuhan tersier) yaitu hukum-hukum yang disyari atkan untuk perkara-perkara yang diangap baik dan sempurna.

Semua ini adalah dasar-dasar yang harus dipeliharakan oleh syara` dalam mengukur teori mashlahat al Mursalat, baik macam-maamnya maupun tingkatannya. Di damping itu dasar-dasar tersebut menggariskan maqashid syar`iyat sebagaimana telah ditunjukkan dalam nash-nash dan berbagi tema, keputusan dan hukum. 
Kemeshlahatan yang dianggap dan dipelihara syara', tidak ada pendangan kata bahwa itu adalah sesuai atau bertentangan dengan hawa nafsu dan syahwat para mukallaf. Akan tetapi kemeslahatan tersebut merupakan sesuatu yang dapat menegakkan kondisi dunia sebagai jembatan akhirat, sehingga terciptalah kehidupan yang baik, utama dan kondusif untuk kebaikan dan kebenaran.

Demikian imam al Syathibi menjelaskan kemashlahatan ini dengan lengkap dalam kitab al Muwafaqat, yang menyatakan bahwa semua pandangan ini adalah karena mashlahat yang disyari ’atkan untuk menegakkan kehidupan dunia, bukan untuk memenuhi hawa nafsu syahawat.

\section{LATAR BELAKANG DAN KRONOLOGI TIMBULNYA METODE AL ISLISHLAH}

Munculnya metode al Istislah ini dalam menetapkan hukum baru yang tidal disebutkan dalam nash Alquran dan sunnah. Karena hal ini tidak ada dalam nashnas tersebut, maka terdorong para ulama dan fuqaha menggunakan kaedah al Istishlah dalam menetapkan hukum baru sesuai dengan syari at Islam. Dari keterangan tersebut, maka dapat diambil empat hal yang mendasar, yaitu:

a. Jalb al Mashalih (menarik maslahat), yaitu perkara-perkara yang dibutuhkan masyarakat untuk membangun kehidupan manusia di atas pondasi yang kokoh, seperti memungut pajak adil sesuai dengan keperluan untuk keperluan pengabdian umum dan peraturanperatuean penting yang bermanfaat. ${ }^{4}$

b. Radd al Mafsad (menolak mafsadat), yaitu perkara-perkara yang memudharatkan manusia baik secara individu maupun kolektif, baik materil maupun spirituil. Mengenai kaedah-kaedah ini diambil barometernya dari nash-nash yang telah dapat dan mewujutkan sistem Islam.

c. Syadd al Zarai (menutup jalan), yaitu memutup jala yang dapat membawa kepada menyia-nyiakan perintah syariat dan

${ }^{4} \mathrm{Al}$ Syathibi, Al I`tisham, juz. II, (t.t.), hlm.295. 
memanipulasinya, atau dapat membawa kepada larangan syara meskipun tanpa disengaja. ${ }^{5}$

d. Takhayyur al Zama (perubahan zaman), yaitu perobahan kondisi manusia, akhlak-akhlak, tuntutan-tuntuta umum yang berbeda dari masa ke masa.

Keempat hal ini menjadi dorongan para ulama dan fiqaha` dalam untuk menempuh metode Istishlah ini dengan tujuan untuk memperbaharui hukumhukum sosial dengan sebaik-baiknya, agar dapat terwujudanya hasil hukum yang terbaik yang sesuai dengan kebutuhan masyarakan dan tidak bertentangan dengan nash-nash syati at Islam. Jadi, apabila ditelusuri peristiwa-peristiwa fiqh Islam bahwa peristiwa-peristiwa itulah yang menumbuhkan dan membuahkan term al Istislah. Sebuah istilah bahasa yang padat dengan isinya.

Sebelum mengunakan dengan istikah Istishlah, terlebut dahulu digunakan dengan istilah $a l-R a y u$ sebagaiman petunjuk ijtihad yang terdapat dalam fatwa fiqh yang berpijak kepada kaeadah-kaedah syar iyah dan maksudnya, baik dengan jalan qiyas atau perpindahan qiyas kepada hukum lain yang berlawanan dengannya karena melihat tuntutan mashlahat. Hal ini dilakukan ketik tidak ada nash, atau menurut ijtihad fuqaha terdapat kekhususan atau ta`wil dalam memahami prtunjuk dan maksud syara`.

Inilah yang telah dirintis oleh Umar bin Khaththab ra. dalam menghadapi berbagai persoalan baru. Seperti larangan Umar ra untuk membagi tanah-tanah (warna) hitam di Iraq kepada para penakluknya, seperti pembahagian harta ghanimah sebagaimana yang telah manqul (telah ditetapkan nash). Demikian juga keputusan Umar mengenai masa iddah bagi isteri orang yang mafqud. ${ }^{6}$ Masalah musytarakah dalam kewarisan dan lain-lain.

Tindakan Umar terhadap hukum yang baru menjadi dasar lahinya kelompok ahl al Ra yi yang menjadi tandingan bagi ahl al Hadis yaitu kelompok yang

${ }^{5} \mathrm{Al}$ Zarqa`, Hukum lslam dan .........., hlm.42.

${ }^{6}$ Mafqud adalah orang yang tidak diketahui khabarnya, tidak diketahui tempat tnggalnya, dan tidak diketahui hidup atau matinya. Akan tetapi, apabila diketahu keberadaannya, maka dinamakan ghaib bukan mafqud. 
terkait oleh arti harfiah nash tanpa melihat illat-illat, maksud-maksud syara` dan nilai-nilai mashlahat yang dijadikan illat dan dimaksud oleh nash.

Kemudian pada masa Imam Abu Hanifah yang menjadi pusad ahl al ra'yi, telah muncul dari lisan Abu Hanifah al Istihsan. Muncul istilah ini ketika dia berdiskusi dengan taman-tmannya menganai masalah-masalah fiqh. Ketika Abu Hanifah memperhatikan bahwa penetapan hukum dengan menggunakan qiyas akan membawa kesulitan dan kesempitan seraya berkata : "saya akan beristihsan seperti ini dan ini”. Kemudian Abu Hanifah menetapkan hukum yang berlawanan dengan qiyas, akan tetapi lebih dekat kepada keadilan, hikmah ditetapkan syara', dan mashlahat maksudnya lebih dekat kepada ruh syari at.

Menetara Imam Malik menggunakan kata al Istihsan sebagai ungkapan dari ra`yu, sehingga ia mengungkapkan perkataan yang populer, yaitu : Al Istihsan adalah tis`ata asyr (sembilan belas) ilmu.

Kemudian para fuqaha' penganut mazahab Maliki (Malikiyah) melahirkan istilah maslahah al mursalah ketika mereka membutuhkan petunjuk dalam memutuskan masalah-masalah baru ang tidak ada nashnya dan qiyasannya. Setelah kata istihsan digunakan dalam pengertian yang luas, lalu datan teori maslahah al Mursalah, maka kata istihsan menjadi sebuah istilah yang memiliki pengertian yang terbatas, yang pengertiannya hanya menunjuk kepada perkara yang berlawanan dengan kaedah-kaedah qiyas.

Katika ilmu Ushul Fiqh sudak memiliki ushlub manhaj (metode tersendiri), maka istilah ini dipakai digunakan dengan istilah al Munsib yang berarti hikmah, illat atau maslahat. Kemudian disebut pula dengan istilah al munsib al mursal yang berarti al mashlahah al mursalah.

Pada masa hukum berkembang sampai zama al Ghazali abad ke 5 hijriyah, muncullah istilah baru yang banyak disebutkan dalam kitab al mustashfa, diantaranya adalah istilah istishlah yang diambil dari kata mashlahat, sebagai 
petunjuk kepada teori mashlahah al mursalah. ${ }^{7}$ Kata Isltishlah memiliki bentuk yang sama dengan Istihsan, istilah ini adalah istilah yang baik dan sesuai.

Demikian juga Istihsan ditetapkan sebagai bahagian dari teori mashlaha al mursalah, khususnya karena istihsan berpindah dari tuntutan petunjuk qiyas atau kardah umum dalam mashlahah tertentu, karena terdapat mashlahah syar iyah (yang ditetapkan oleh syara'), yang mengharuskan adanya perpindahan ini.

Demikian juga penggunaan istilah al siyasah al syar`iyah, yang kemungkinan besar istilah ini digunakan dalam mazhab Abu Hanifah dan mazhab-mazhab yang lain. kemudian mereka menunjukkan sesuatu pemahaman kepada konsep Istihsan dan istishlah, yaitu pada waktu membahas maslah hak ‘uqubat ta`zruyah (sanksi ta`zir). Teori Istishlah banyak digunakan dalam pembahasan al siyasah al syar iyat.

\section{HUKUM FIQH YANG DITETAPKAN OLEH METODE AL ISTISLAH}

Hukum yang titetapkan oleh ijtihad Istishlah berdasarkan kaedah mashalih al Musalah. Maka hal ini terbagi kepada dua macam: ${ }^{8}$

Pertama: Hukum yang berkaitan dengan urusan administrasi. Hukum ini diatur untuk kemaslahatan sosial, yaitu peraturan-peraturan yang diperlukan untuk kemslahatan umum. contohnya pajak yang digunakan untuk kepentingan umum, seperti membagun, persiapan prang, sensus penduduk, sertifikan tanah, panti-panti asuhan dan berbagi macam jaminan sosial lainnya. Semua ini dapt menghindari dari kesulitan dan dapat mendatangkan kebaikan seperti mendapat pekerjaan bagi orang yang nganggur, dan merealisasikan kehidupan yang layah yang paling minimal adalah mafah pokok kehidupan manusia.

Semua kemeslahatan tersebut yang sangat dibutuhkan adalah keidupan umum, wajib saling tolong-menolong, yang kuat membantu yang lemah, yang kaya membantu yang miskin. Hal ini semua termasuk tuntutan umum bagi pemegang kekuasaan tertinggi dalam sebuah negara. Karena itu, maka miliknya bahkan kewajibannya menciptakan aturan-aturan, mendirikan lembaga-lembaa

${ }^{7}$ Teori Mashlahah al Mursalah maksudnya membangun hukum baru yang sesuai dengan mashlahah al Mu'tabarahmenurut syara'. Adapun ungkapan mashlahah al mursalah menunjukkan makna zat (esensi) dari mashlahah, bukan berarti membangun hukum berdasarkan tuntutannya.

${ }^{8} \mathrm{Al}$ Zarqa`, Hukum lslam dan ..., hlm.48-52. 
institusi-institusi, menetapkan aturan-aturan yang laizim untuk membanguk semua aspek-aspek ini. Menetapkan batasan-batasan tindakan bagi seseorang yang melanggar sesuai dengan kesalahan yang dilakukannya.

Kedua: hukum-hukum yang berkaitan dengan aturan dan sistem peradilan dan hak-hak tertentu (khusus). Hal ini dapat dilihat dalam beberapa contoh berikut ini:

1. Sistem Peradilan

a. Pembentukan lembaga-lemabag peradilan masa lalu untuk dapat dijalankan pada masan kini.

b. Pembukuan kasus, dimana kasus yang harus dicatat adalah peristiwaperistiwa yang terjadi, saksi-saksi dan hukum-hukum yang ditetapkan, dengan tujuan untuk mempekuat dan memeliharakan hak-hak, serta mencegah dari berbagai manipulasi. Hal ini tidak terpikir masa sebelumnya.

c. Adanya spesialisasi hakim sesuai dengan problem dan kasus yang diajukan/dihadapi. Setiap dakwaannya ada mahkamah (peradilannya) khusus yang menanganinya, dan mahkamah tersebut tidak boleh menangani maslah masalah yang bukan bidangnya. Seperti mahkamah yang menangani bidang pidana (Jinayat) dilarang menangani masalah yang berkaitan dengan mahkamah perdata (huquqiyat), demikian juga mahkamah cabang (juziyat) yang menangani hanya bahagian yang ringan saja, dan lain-lain.

d. Mahkamah sekarang membuar sidang bertahap, sehingga (2 atau 3 tahap), sehingga yang terpidana memiliki kesempaan untuk berfikir, menerima atau menolek keputusan sindangnya di hadapan mahkamah yang lebih tinggi yang dapat merobah atau membatalkan bila terdapat kekeliruan atau ketidakadilan.

e. Para penguasa dan fuqaha' melarang mendengar dan menerima laporan yang diajukan sudah lewat waktu, karena pemilik hak tersebut membiarkan tuntutan terhadapnya dalam jangka waktu yang lama tanpa uzur. Jadi peradilan yang seperti ini sudah dianggap bebas dari 
tanggung jawab tentang permasalahan yang dihadapinya. Peraturan ini dikenal dengan istilah qadhiyyat al taqaddum (kasus yang tela lewat), atau masalah yang telah lewat waktu yang ditetapkan oleh para fuqaha' mutaakhkhirin lalu dikeluarkan oleh Amir atau penguasa yang berkuasa pada masanya.

\section{Hak-hak Khusus}

Memutuskan perkara bagi yang tidak ada kahabarnya, apakah dia sudah menghilang atau sudah mati. Seperti melepaskan perkawinan bagi orang yang mafqud $^{9}$ dengan isterinya berdasarkan permintaan isterinya, meskipun tidak dapat dipastikan kematian suaminya. Putusan ini (misalnya) setelah lewat empat tahun dalam kondisi damai dan satu tahun dalam kondisi perang, kalau suaminya belum pulang, maka hakim, boleh memutuskan perkawnannya, dan isteri diperblehkan menikah kembali denan laki-laki lain. Keputusan ini ditetapkan untuk menolak kemudharatan ang akan menimpa isteri jika tetap muallaqah (tergantung) tanpa adanya kepastian dalam jangka waktu yang sudah lama.

Dalam contoh lain, eksistensi perundang-undangan dengan menetapkan bahwa transaksi tanah yang dilkukan oleh orang yang bertransaksi tidak dapat mewujudkan hak-hak tertentu dalam pertanahan sebelum dicatat dalam catatan pertanahan. Hal seperti ini bertujuan untuk mengatur kemeslahatan diantaranya agar orang memiliki tanah tidak dapat dikelabui dengan ukuran dan harganya.

Demikian juga mengenai utang-piutang. Undang-Undang masa sekarang melarang melakukan utang-piutang yang melewati batas yang telah ditetapka batas-batas tertentu tanpa ada bukti-bukt tertulis. Hal ini berangkan dari kenyataan yang melakukan transaksi kedustaan dari saksi-saksi ang berupa orang. Kesemuanya ini merupakan pembentukan hukum yang ditentukan oleh tuntutan kaedah mashalih al mursalah dalam persoalan hak-hak tertentu.

\section{TEORI AL ISTISLAH DALAM PANDANGAN MUJTAHID}

Dalam memandang al Istislah (bahkan termasuk al Istihsan), para Imam Mujtahid (imam mazhab) memiliki pandangan yang berbeda. Mereka memiliki

${ }^{9}$ Mafqud adalah orang yang tidak diketahui khabarnya, tidak diketahui tempat tnggalnya, dan tidak diketahui hidup atau matinya. Akan tetapi, apabila diketahu keberadaannya, maka dinamakan ghaib bukan mafqud. 
sikap yang jelas dalam melihat istilah ini, baik bersifay positif maupun negatif, kecuali mazhab Syafi i.

Maka oleh karena itu dapat dilihat penjelasan sikap berikut ini secara ringkas dari masing-masung mujtahid, yaitu:

\section{Mazhab Abu Hanifah (80-150 H / 699-767 M)}

Mazhab Hanafi tidak mengkaji mengenai al Istishlah secara khusus, akan tetapi selalu al Istishlah ini di kajikan bersamaan dengan al Istihsan. Al Istihsan dan al Istishlah adalah dua istilah yang memiliki makna yang sama, namun istilah yang digunakan adalah mashlahah al mursalah (sama dengan mazhab Maliki), sedangkan istilah al Istihsan adalah penggunaan istilah sudah jelas, sebagaiman yang telah tersebut. Mereka menetapkan al Istihsan di atas aturan yang sistematis, yaitu ketika perlu meluruskan kejanggalan yang timbul dari (penerapan) qiyas. Hal ini dengan melihat gaya dan tujuan syariat itu meluruskan kejahatan dan menegakkan keadilan dan kemeslahatan.

Dalam kajian Istihsan, mazhab Hanfiyah membagi istihsan menjadi dua macam, yaitu: Istihsan qiyasi dan istihsan dharurat. Istihsan qiyasi dapat dijelaskan dalam permasalahan qiyas, karena merupakan bahagian dari qiyas, sedangkan istihsan dharurat adalah menjadi syaqif (saudara) bagi al Istishlah.

Dalam mengkaji Istislah, (dalam mashab Hanafiyah dinamakan dengan maslahah al mursalah), ini tidak mengkajinya secara tersendiri yang dapat menjelaskan cara dan syarat-syarat mereka dalam memelihara mashlahat. Hal ini tidak seperti apa yang telah di laksanakan oleh mazhab Maliki, fuqaha' Hanafiayah banyak membuat furu dan berfatwa dengan fatwa istihsaniyah yang masuk pada istihsan dharurat, yang menurut mereka istihsan dharurat tersebut berpijak pada pemeliharaan terhadap maslahat, menghilangkan kesempitan dan siasa syar iyat (figh siyasah). Sementara pandangan selain mazhab Hanafiyah, bahwa istihsan dharurat ini mencakub mashlahah mursalah, sebagaimana telah dijelaskan.

Contohnya: dalam mazhab Hanafiyah berfatwa bahwa seorang perempuan yang akan murtad jika suaminya mentalk bain, maka dia tidak tertalak bain. Demikian juga berfatwa bahwa isteri yang ditalak oleh suaminya, sedangan 
suaminya sedang sakit, maka isteri berhak mendapatkan warisan, kerena suaminya meninggal, sedangkan isteri dalam iddah.

Maka, Istihsan adalah perkata yang dianggap baik oleh para mujtahid dengan berpijak kepada tabi 'at, adat, atau sepertinya tidak ada amarah (indikator) dari syari at.

\section{Mazhab Malikinyah (93-179 H/ 712-795 M)}

Mazhab Maliki telah menampakkan teori maslahat al mursalat dalam gambaran yang lebih umum. Mereka menjadikan Istihsan sebagai cabang dalam penggunaan maslahat al mursalah yang dikhususkan untuk keadaan yang berlawanan dengan aturan qiyas. Dimana kalau menerapkan mashlahat tang berlawanan dengan qiyas, maka akan dapat menjauhkan kesulitan yang ditimbulkan oleh qiyas.

Dalam mazahab Maliki, memandang mashlahat al mursalat sebagai sumber tersendiri. Anggapan ini adalah sangat populer dalam mazhab ini, karena nashnash syariat telah menunjukkan demikian sebaaimana dalam masalah qiyas. Ketika hukum syara' dibangun di atasnya dalam sebuah peristiwa dalam nash syariat atau qiyasnya, maka mashlahat al murstalah merupakan dalil kalu tidak ada dalil selain itu. Jadi apabila dilihat dari pandangan al Istihsan, maka mashlahat al murslah menrupakan dalil yang berlawanan dengan qiyas.

Ketika adanya penjelasan pendapt mazhab Maliki mengenai al Istihsan dan al Istislah, menetapkan bahwa imam Malik memberikan tiga batasan yang dapat menghilangkan kekhawatiran terhadap dan menghindari kekacauan pemikiran dari jalannya, sehingga kriteria mashlahat tidak mengikti hawa nafsunya. al Syathibi mengemukakan dalam kitab al Yitisham, ada 10 contoh mengenai al Istihsan dan al Istishlah yang telah titetapkan oleh para shahabat dan tabi in. Sehingga kesimpulan yang dapat ditarik menjadi tiga batasan sebagaimana anggapn mazahab Makilyah. Batasan-batasan tersebut adalah:

a. Adanya kesesuaian antara mashlahat dengan maqashid al syariah, dimana mashlahat tersebut tidak bertentangan dengan dalil syara walaupun satu. 
b. Mashlahat tersebut berkaitan dengan permasalahan yang ma $q u$ lat (rasional) yang menurut syara' didasarkan kepada pemeliharaan terhadap mashlahat, sihingga tidak ada tempat permasalahan yang membicarakan tentang ta`abbud dan masalah syara`yang sejenisnya.

c. Hasil dari mashalat al murslah dikembalikan kepada perkara yang dharury (primer) menurut syara' dan menghindari dari kesempitang dalam agama, sehingga lahirnya kaedah "tidak sempurna sesuatu yang wajib kecuali dengannya", ${ }^{10}$ maka dia wajib.

Dari uraian di atas dapat diambil kesimpulan bahwa mazhab Abu Hanifah dan mazhab Maliki memiliki pandangan yang sama dalam memandang teori al Istishlah. Akan tetapi imam Maliki karena dalam sejarah kehidupannya berbeda sesudah mazhab Hanafi, maka imam Maliki memperdalam konsep mashlahah al Mursalah dan syarat-syaratnya, sehinga teori tersebut menajdi jelas dalam mazhab ini, sehingga mereka populer dengannya.

Imam al Syathibi dalam kitam al Muwafaqat dan al I'tisham, serta para ulama ushul lainya menjelaskan bahwa hukum syara terbagi menjadi dua, yaitu: (1). hal yang berkaitan dengan akhirat yang disebut dengan ibadah. Dalam urusan ini tidak ada ruang untuk menkaji illat dan mashlahatnya, karena hal ini bersifat ta abbudi. (2). hal yang berkaitan dengan muamalah, yaitu selain ibadah seperti adat, muamalah dan lain-lain. maka dapat dikaji dan mempunyai illat kemeslahatan manusia dan diikat dengan nilai-nilai kemeslahatan dalam kehidupan sebagimana yang terdapt dalam nash-nash syariat. Imam Maliki telah memperluaskan kajian ini terhadap illat-illat dan nilai-nilai mashlahat tersebut dalam urusan muamalah ini, shingga mereka membuat sebuah kaedah (teori) mashlahah al mursakah dan al istihsan. Imam Malik menatakan bahwa "Istihsan merupakan sembilan persepuluhnya ilmu". ${ }^{11}$

Mazhab Hanafiah memegang teguh dalam penggunaan teori al Istihsan yang merupakan jalan keluar dari kaedah qiyas umum karena sesuatu yang lebih kuat, karena dahrurat yang menarik kemeslahatan dan menolak kemafsadatan. Abu

${ }^{10} \mathrm{Al}$ Syathibi, al T tisham, juz II, hlm. 307 dan 315.

${ }^{11} \mathrm{Al}$ Syathibi, Al Muwafaqat, juz II, hlm. 308. 
Hanifah banyak menggunakan al Istihsan dalam memecahkan berbagai masalah, dimana ia telah melakat dalam menggunakan jalan ini. Di sisi lain Mazhab Hanafiyah berpendapat bahwa memperhatikan mashlahat dan keluar dari jalan qiyas apabila bertentanan dengan maslahat merupakan sebuah al Istihsan. Hal ini menunjukkan bahwa mereka berpendapat harus memperhatikan mashlahah al mursalah, dan membangun hukum berdasrkan aulawiyah (keutamaan). Ketentu ini tidak bertentangan dengan aturan qiyas, dan ini adalah makna dari Istishlah sebagaimana telah dijelaskan. Maka oleh karena itu, tidak mingkin terjadi apabila mengakui Istihsan dan tidak mengakui Istishlah, karena kedua istilah tersebut memiliki kaitan yang erat.

Jadi dapt dilihat bahwa, antara mazhab Hanafiyah dan mazhab Malikiyah memiliki pandangan yang sama mengenai al Istishlah dan al istihsan. Namun memiliki perbedaan dalam penggunakan Istilah. Abu Hanifah mengambil jalan Istihsan menuju kepada Istishlah, sedangkan imam Maliki sebaliknya mengambil jalan Istishlah menuju Istihsan. Masing-masing mazhab memiliki teori dan metode tersendiri dalam memahami hukum syara', dan mempopulerkan teori masing-masing.

\section{Mazhab Syafi iyah (150-204 H/ 769-820 M)}

Menurut pandangan Imam Syafi`i bahwa hukum syara` telah menanggung seluruh problem yang ada melalui nash Al Quran dan Sunnah, isyarah maupun dengan jalan qiyas. Jadi kalau menggunakan istihsan dan istishlah yang pada hakikatnya tidak dapat dibatasi mengenai permasalahan hukum (syari at). Jadi kalau menggunakan jalan Istihsan dan Istishlah akan menjadikan kebenaran dan kebathilan tidak dapat diukur. Syafi i berkata : "Barang siapa yang beristihsan, maka ia telah membuat syariat"..... Maka menurutnya, kalau seorang mufti, hakim atau mujtahid mengunakan jalan istihsan, maka tentu saja urusannya menjadi sia-sia.

Imam Syafi'i telah menjelaskan secara khusus dalam kitab al Umm dinamakan "Pembatalan terhadap Istihsan". Maka seorang mujtahi tidak boleh membuat istihsan, dan batang siapa yang beristihsan, berarti dia telah membuat 
syariat. Maksudnya, bagi seorang mujtahid dituntut menetapkan hukum syariat bukan membuat syari’at.

Jadi, sikap imam Syafi i terhadap istihsan dan istislah itu tidak jelas, sehingga pendapat para fuqaha' mazhabbya dalam melihat masalah ini menjadi idhthirab (tidak jelas). Imam Syafi i menyerangan dalam pembatalan terhadap Istihsan dengan penyarangan yang tidak ada kompromi.

Populeritas Istihsan dalam mazhab Hanafi dan Istishlah ini adalah dalam mazhab Maliki dengan istilah maslahah al mursalah. Jadi Imam Syafìi berpendapat dengan istihsan berarti menganggap bahwa Allah swt. telah meninggalkan sebahagian kemeslahatan makhluknya. Allah tidak mensyariatkan hukum yang memashlahatkan mereka dan memeliara merka dari kemafsadatan. ${ }^{12}$

$$
\text { أيحسب الإنسان أن يترك سدى }
$$

Artinya: "apakah manusia menduga bahwa ia dibiarkan sa-sia"13

Dari ayat ini padahal Allah telah menurunkan hukum selengkaplengkapnya. ${ }^{14}$ Demikian juga Syafi i telah berkata bahwa" tidalkah diturunkan suatu peristiwa kepada manusia, melainkan Alquran telah menunjukkan ketentuan yang baik secara nash (khusus) maupun umum (global). Jadi istihsan dapat diingkari (menurut al Stafi i) demi berpegang kepada kemaslahatan yang tidak didukung oleh syariat waluun secara global.

Menurut Al Ghazali, bahwa setiap mashlahat yang tidak beruju’ kepada pemeliharaan terhadap maksud yang dipahami dari Alquran, Sunnah dan Ijma`.mashlahatseperti ini temasuk mashlahat gharibah (aneh), dan tidak sesuai dengan tindaka-tindakan syara.$^{15}$

Jadi jelas, bahwa mashlahat semacam ini datannya dari hawa nafsu dan syahawat yang bertentang dengan maksud syara' dan bukanmashlahah mursalah sebagaiman dimaksudkan oleh Istishlahiyyun dan Istihsaniyun. Mereka membuat mashlahat sesuai dengan maksud syara` dan kaedah-kaedahnya yang diambil dari

\footnotetext{
${ }^{12} \mathrm{Al}$ Zarqa', Hukum lslam dan hlm.70.

${ }^{13}$ QS.Al Qiyamah/75: 36

${ }^{14}$ QS.Al Maidah / $5: 3$

${ }^{15} \mathrm{Al}$ Ghazali, Al Mustashfa,
} 
berbagai nash dan dalil-dalil syara`. Jadi karena terbuka jalan ini, maka merka mewajibkan menempuh jalan ini, sehingga apabila tidak, maka hukum-hukum syara`yang menyimpang dari sasaran yang dimaksud dan tujuantujuan syara` menjadi tidak tewujud.

Pendapat Syafi'i mengenai Istihsan dan Isishlah, dimana antara sesuatu ayng tersirat dengan sesuatu yang tersura tidak sejalan dalam hal keumuman dan kemuthlakan. Apabilah melihak apa yang tersirat, maka dapt ditemukan bahwa perbedaan hampir-hampir sama, namun hanya terbatas pada istilah dan pemahamannya saja dan bukan pada hakikat istihsan dan Istishlah.

Menurut pendapat Al-Juwaini (w.478), ${ }^{16}$ mengenai sikap Imam Syafi`i terhadap Istishlah yang ternyata bersikap positif, sebagaimana sikab Abu Hanifa dan shahabat-shahabatnya, dimana Al-Juwaini menjelaskan dalam kitab al burhan fi ushul fiqh bahwa "Syafi`i dan shahabat-shahabat Abu Hanifah berpegang kepada Istidhlal walaupun tidak disepakati kepada hukum yang disepakati dalam asal. Walaupun demikan, Syafi'i mengkaitkan hukum-hukum dengan nilai-nilai yang mursalah (tidak dijelaskan oleh nash), kemudian kalau nilai-nilai tersebut tidak ada, maka melihat kepada asal yang lebih dekat penyerupaannya. ${ }^{17}$

Menurut al Juwaini, kata Istidlal dalam mazhab Syafi`i mirip dengan Istishlah. Mereka mengatakan Istidlal Mursal, sebagaimana kata ma ani al mursal berarti maslahah mursalah, kadang-kadang dikatakan manasib mursal. Jadi menurutnya, imam Syafi i memberi syarat dalam mengikuti mashlahat mursalah, yaitu mashlaha tersebut harus dekat dengan nilai-nilai ushul yang thabit. Demikia juga pandapat dari para ulama Istishlahuyyun. Hal ini memperkuat hakiakah mashlahat, dan tidak mengeluakan bahagian-bahagian mashlahat, yang seolaholah syarat yang memperjelas dan bukan mentaksiskan.

Imam Al-Ghazali mengakui dan mengikuti prinsip-prinsip istihsan dan istishlah, sebagai hujjah dalam menetapkan hukum, bahkan al Ghazali dapat menjadikan mashlahah mursalah dapat mentakshishkan nash-nash Alquran dan

\footnotetext{
${ }^{16}$ Nama lengkap al Juwaini adalah Abu al Maali Abd al Mulk bin Muhammad al Juwaini.

${ }^{17}$ Mushthafa Zaid, Risalah al Mursalat fi al Tasyri al Islami, ed.I, (Dar Fikri Aabiy, t.t), hlm.40. lihat: Al Juwaini, al Burhan fi Ushul Fiqh, (Dar al Kutb, t.t), hlm. 331
} 
sunnah. Sehingga al Ghazali membuat tiga syarat untuk mashlahat untuk menjadikan sebagi hujjah al mu`tabarah, yaitu:

a. mashlahat tersebut harus dharuriyah (Primer), Al Ghazali membagi mashlahat menjadi tiga bahagian yaitu dharuriyah, Hajjiah dan tahsiniyah.

b. Mashlahat harus qath $i$ (pasti), pasti dapat disampaikan tujuan yang dharuriyah.

c. Mashlahat harut Kulliyat (umum), yaitu dapt menghidari kemudharatan manusia secara umum bukan individu.

Ketiga syarat mashlahat tersebut, dapat dijadikan hujjah yang cukup untuk menetapkan hukum, walaupun tidak didukung oleh dalil syara' tertentu. Contoh: dalam menyerang musuh walaupun harus membunuh tawanan muslim. Dalam kondisi seperti ini adalah sebua kemeslahatan yang dharuriyat, qath iyat dan kulliyat. Tidakan ini wajib dilakukan walupun terbuhunnya tawanan muslim.

Adapun masalah-masalah yang hanya menempati posisi hajjiyah dan tahsiniyah, maka tidak boleh menetahkan hukum seperti ini, tapi hanya berpegang kepada mashlahat yang tidak didukung oleh dalil syara`, maka hal ini digolongkan kepada qiyas.

Dalam hal ini dap diambil kesimplan, bahwa syarat-syarat yang telah dikemukakan oleh al-Ghazali yang berkaitan dengan mashlahah almurslah dapat dijadikan sebagai hujjah, yaitu syarat dharuriyat, qath iyat, dan kulliyat, yang pada hakikatnya dapat mendahulukan mashlahat al mursalat dari nash, dan semua syarat tersebut semata-mata untuk memperhatkan mashlahat.

Menurut Izzuddin bin Abd al Salam ${ }^{18}$ dari apa yang telah ditetapan oleh al Juwaini tentang cara imam Syafi`i dalam beristidlal, maka Izzuddin bin Abd al Salam menetapkan sebuah metode penelusurannya, sehingga Izzuddin bin Abd al Salam berpendapat dalam kitab Qawaid al Ahkam fi Mashalih al Anam; "Seandainya keharaman melandan secara umum di sebuah negara, tidak ditemukan lai makanan yang halal, maka boleh mengunakan yang haram sekedar keperluas saja, tanpa harus menuggu samapi datangnya kemudharatan, karena

\footnotetext{
${ }^{18}$ Nama lengkap Izzuddin bin Abd al Salam Al Syafi ’i, (wafat tahun 660)
} 
kalau menunggunya akan melemahkan manusia, sehingga orang kafir dan munafiq akan senang dan menguasai negara Islam.

Pendapat 'Izzuddin yang lainnya adalah "Barang siapa yang menelusuri maksud-maksud syara` dalam menarik kemeslahatan dan menolak kemafsadatan, maka ia akan memperoleh keyakinan atau pengetahuan bahwa maslahat ini tidak boleh disia-siakan dan mafsadat tidak boleh didekati”. Pendapat Izzudin ini menganjurkan untuk menelusuri dan mendukung dalam penggunaan teori Istislah. menurutnya "Kebaikan" adalah menarik kemashlahatan dan menolak kemafsadatan."20

Dalam kitab tersebut Izzuddin menjelaskan bahwa dalil-dalil syara` ada lima, yaitu: Alquran, Sunnah, Ijma', Qiyas shahih dan Istidlal Mu`tabar. ${ }^{21}$ Ia menambah satu dalil yaitu Istidlal al mu`tabarah. Jadi, setelah qiyas shahih tidak ada dalil yang lain selain kaedah Istihsan dan Istislah dalam memecahkan persoalannya. Demikian juga, banyak didapati bahwa Izzuddin sendiri banya menyebut-nyebutkan kelima sumber tesebut, timbul sebuah statemen bahwa seseorang tidak boleh beristihsan dan mengamalkan mashlahah al Mursalah, begitu juga melarang bertaklid kepada orang yang tidak boleh diikutinya. Istihsan termasuk perbuatan yang batil, karena tidak ada dalil dan tidak ada faedah dan (dugaan) yang dapat dijadikan hukum syara`.

\section{Mazhab Hanabilah (164-241 H/ 780-855 M)}

Mazhab Hanabilah muncul dengan menempuh jalan sebagaimana Imam Maliki, bahwa memandang mashlahat sebagai salah satu sumber yang dapat dijadikan sebagai pegangan dalam menetapkan hukum syara`. Menurut mazhab Hanabilah, seorang faqih dapat menetapkan bahwa setiap perbuatan yang mengandung mashlahat yang ghaib dituntut oleh syara` anpa perlu nash-nash syara`yang khusus, dan setiap perkara yang mendatangkan mudharat yang lebih

${ }^{19}$ QS.Al Zalzalah/99: 7-8. 7. Barangsiapa yang mengerjakan kebaikan seberat dzarrahpun, niscaya dia akan melihat (balasan)nya. 8. Dan barangsiapa yang mengerjakan kejahatan sebesar dzarrahpun, niscaya dia akan melihat (balasan)nya pula.

${ }^{20}$ Izzuddin Bin abd al Salam, Qawa id Ahkam fi Mashalih al Anam, juz.II, hlm 181-182.

${ }^{21}$ Izzuddin, Qawa`id Ahkam ......, juz.II, hlm 46. 
besar dari pada manfaatna, maka hal itu dilarang tanpa perlu adanya nash-nash yang khusus pula.

Dengan demikiam, Ahmad bin Hambal memandang mashlahah mursalah dan batas-batasnya sebagaimana pandangan imam Maliki. Namun pada hakikatnya Ahmad bin Hanbal tidak mengakui mashlahah mursalah sebagai sumber hukum yang berdiri sendiri sebagaimana pandangan imam Maliki, bahkan Hanabilah menganggap mashlahah mursalah sebagai bahagian dari qiyas.

Maka oleh karena itu, seakan-akan, qiyas menurut Hanabilah terbagi menjadi dua, yaitu qiyas khash (khusus) dan qiyash `amm (umum). Qiyas khas adalah qiyas yang memiliki illat yang sama yang berkumpul dalam dua perkara yang sama, sedangkan qiyas ‘am adalah qiyas yang masuk di dalamnya permasalahan yang mempunyai illat secara 'am (umum), yaitu hikmah dan mashlahat. Nampaknya dalam mazhab Syafi iyah memiliki pandangan seprti ini juga dalam pembahagian qiyas, dan pengakuannya terhadap hukum mashlahat dari aspek qiyas umum. ${ }^{22}$

Menurut Najmuddin al-Thufi (dari mazhab Hanabilah), pandangannya sangat kontadiksi dengan pendapat para ulama dan fuqaha di atas mengenai mashlahat, dia mendahulukan mashlahat dari pada nash atau dalil qath $i$ apabila keduanya bertentangan. ${ }^{23}$

Pendapat ini jelas sebuah ra`yu yang ditolak oleh semua mazhab fiqh yang mu tabarah, bukan hanya oleh mazhab Ahmad bin Hmabal saja, karena pendangan ini akan membawakan kepada menyia-nyiakan nash-nash syari’at hanya karena pandangan akal semata. Seandainya diperbolehkan kepada mujtahid, hakim dan ulama lainnya berijtihad seperti ini, tentu saja akan mengalami kekacauan dalam mengistimbathkan dan mengamalkan sebuah hukum.

Karena itu, para ulama dan fuqaha' sepakat untuk menolak pandangan ini, karena kalau mereka setuju dengan pendapat ini, sudah barang tentu menimbulkan kekacauan dalam kaedah-kaedah hukum khususnya mengenai kaedah Istishlah

${ }^{22}$ Izzuddin, Qawa id Ahkam ......, juz.II, hlm 181.

${ }^{23} \mathrm{Al}$ Syathibi, Al Muwafaqat, juz II, hlm. 82. 
untuk membedakan mashlahat dan mafsadat, serta menetapkan batasan-batasan yang cukup.

Dalam mencegah kekacauan terhadap teori Istislah ini, maka dapt ditetapkan beberapa kriterianya, yaitu bahwa mashlahat tersebut harus mashlahah mursalah, artinya mashlahat yang tidak terdapat nashnya dalam syari at, baik dalam bentuk perintah maupun larangan. Demikian juga harus sesuai kaitannya dengan tiga rumusan mashlahat bagi hukum-hukum yang disusun (oleh Imam al Ghazali) untuk kehidupan masyarakat, yaitu: dharuriyat, hajjiyat dan tahsiniyyat.

\section{Mazhab Ibadhiyah Kawarij}

Pemikiran ushul Fiqh mazhab Ibadhiyah ${ }^{24}$ mengakui adanya teori mashlahat murslah sebagai dalil yang shahih dalam ushul fiqh mereka.

Diantara ulama ushul Fih mereka adalah Abu Muhammad bin Abdullah bin Hamid al Salimi al Ibadhi menjelaskan dalam kitabnya ${ }^{25}$ bahwa diantara Istidlal adalah mashlahah mursalah, yaitu sebuah ungkapan dari manasib yang mengandung kemeslahatan hamba dan tertolaknya afsadat dari mereka. Akan tetapi pembuat syari at tidak memperhatikan sifat manasib tersebut, baik dalam bentuk maupun jenisnya dalam menetapkan hukum, dan tidak diketahui pula penolakan dari pembuatan syara`. Oleh karena itu pembuatan syara` diberi nama dengan mursal, karena mursal menurut bahasa adalah muthlak, sehingga seolaholah sifat munasib ini dimuthlakkan (dilepadkan drai pengakuan dan penolakan.

Selanjutnya Abu Muhammad bin Abdullah bin Hamid al Salimi al Ibadhi mengatakan, bahwa apabila memperhatikan pendaparmazhab Ibadhiyah, maka ia akan dapt menerma manasib seperti ini, dan ia membuat illah denganya kepada perkara yang titunjukan olehnya secara global, yaitu kalau tidak ada dalil yang

\footnotetext{
${ }^{24}$ Pendiri mazhab Ibadhiyah adalah Abdullah bin Ibadh (w.85/86 H). ia belajar ilmu dari Jabir bin Zaid, termasuk tokoh tabi in yang berguru kepada Ibnu Abbas. Imam al Bukhari memeasukkanny kedalam kitab shahihnya. Ibadiyah membangun fiqihnya dari fiqh Jabir bin Zaid. Pada mulanya Ibnu Ibadh mempunyai hubungan dengan Nafi bin Asraq, kemudian dia memisahkan diri dari Nafi bin Azraq karena pertimbangna siyasah (politik) kemudian terputuslah ilmu darinya dan iapun bebas mengemukakan pemikiran fiqihnya. Oleh karena itu sebagaian tokoh kontemporer menganggap bahwa mazahab Ibadhiyat termasuk mazhab Khawarij. Sementara dari pihak penganut mazhab Ibadhiyat sendiri yang ada sekarang di Aljazair, Tunisia dan Oman. Mereka menolak anggapan bahwa mereka adalah golongan Khawarij.

${ }^{25}$ Lihat: Abu Muhammad bin Abdullah bin Hamid al Salimi, Syams Ushul; tela ah al syams Syarh al Alfiyah,
} 
mengakui bentuk dan jenisnya, maka dapt diambil dalil-dalil syara' yang menunjukkan pengakuan terhadap mashlahat secara mutlak. Seperti Firman Allah swt.

$$
\text { ويسألو نك عن اليتامى قل إصلاح لهم خير و الله يعلم المفسد من المصلح }
$$

Artinya : "Dan mereka bertanya kepadamu tentang anak yatim, katakalah: "Mengurus urusan mereka secara patut adalah baik, dan jika kamu bergaul dengan mereka, maka mereka adalah saudaramu; dan Allah mengetahui siapa yang membuat kerusakan dari yang mengadakan perbaikan. $^{26}$

Maksud syara` mengakui mashlahat baik secara global maupun terperinci. Karena itu perlu mencantelkan perkara yang tidak diketahui pengakuannya dari pada syara` kepad apa yang telah diakui oleh syara`. Maka hal ini menjadi sebuah keyakinan bahwa Allah menjadikan dan memelihara semua yang ada ini menjadi mashlahat.

Diantara ulama yang mengatakan bahwa diantara istidlal adalah Istihsan sebagaimana disebutkan oleh Abu Hanifah dan golongan Mu'tazilah. Semenrata manyoritas ulama menolah Istihasan, dan Ibnu Hajib menisbathkan pendapat tersebut kepada mazhab Hanabilah. Akan tetapi al Mahalli menolak pendapat Ibnu Hajib bahwa mazhab hanabilah menolak Istihsan. Istihsan dianggap sebuah dalil yang cacat dalam pandangan mujtahid. Sebahagian ulama menafsirkan bahwa istihsan dengan perpidahan qiyas yang lemah kepada qiyas yang kuat. Oleh karena itu tidak ada pendapat yang paling kuat bahwa qiyas yang paling kuat pasti didahulukan dari pada qiyas yang aling lemah.

Melihat perdebatan pendapat tersebut, Mustafa al Zarqa` mengeluarkan pendapatya, bahwa orang yang mengakui Istihsan, maka dia akan mengakui Istislah dan mashlahah musalah dengan standar syara', dan tidak bertentangan denan nash maupun qiyas, serta hal seperti ini dilalui dengan jalan aulawiyah (mengutamakan).

${ }^{26}$ QS. Al Baqarah/2:220. 


\section{Mazhab Zidiyah}

Mazhab Zaidiah adalah bahagian dari mazhab Syi ah. Dalam pengkajian Fiqh mazhab Zaidiyah lebih dekat dengan Mazhab Hanafiyah. Demikian juga pandangan merekan mengenai al Istihsan, baik pembahagian maupun urutannya. Menurut mereka (Zaidiyah) Istihsan adalah perpidahan dari hukum qiyas, karena ada sesuatu yang mengharuskannya. Mereka membagi Istihsan tersebut sebagaimana mazhab Hanafiyah, yatu kepada empat bahagian, adalah: Istihsan qiyasi, Istihsan dharuri, Istihsan Sunnah, Istihsan Ijma`.

Dalam memahami Istihsan qiyasi dan Istihsan sunnah, sama persis dengan pendapat mazhab Hanafiyah. Demikian juga mengenai Istihsan dharuri dan istihsan Ijma $i$, akan tetapi ada sedikit perbedaan dalam memendangnya. Istihsan qiyasi adalah mengutamakan qiyas khafi yang lebih kuat dari pada qiyas jali (zahir), akan tetapi illat dan pengaruhnya lebih lemah.

Mereka meninggalkan qiyas berdasarkan Istihsan, karena melihat maslahat juziyyat pada kasus tertentu. Mereka tidak menyebutkan dengan Istihsan dharuri sebagaimana mazhab Hanafiyat, mereka mengkaitkan dengan Istihsan qiyasi, kemudian menganggap maslahat Juz iyyat sebagai wajah qiyas khafi yang lebih kuat, karena mashlahat adalah sifat yang munasi $^{27}$

Menurut mereka mashlahat dapat dijadikan illat dlam qiyas, sehingga menjadi taarrudh (kontradiksi) antara mashlahat yang merupakan illat umum dengan illat khusus.

Sikap mereka yang positif terhadap Istihsan berarti mematikan mereka, dan dengan jalan awlawiyah (mengutamakan). Mengakui mashlahat mursalah yang tidak ditemukan dalam nash syara`atau qiyas yang berlawanan dengannya. Akan tetapi menurut mereka bahwa nashlahat mursalah itu bukan ashal (sumber) hukum yang berdiri sendiri, melainkan dikaitkan kepada qiyas, karena illat yang berpengaruh dalam qiyas (yang dinamakan dengan al munasib) diantara macammacamnya adalah yang disebut dengan al Munasib mursal, atau al munasib al ghaib, dan mashlahat mursalat menurut di luar mazhab Zaidiyah.

\footnotetext{
${ }^{27}$ Mushthafa Zaid, Risalah..., hlm.41.
} 
Pendapat ini serupa denga pendapat yang membagi qiyas menjadi qiyas khas dan qiyas am, sebagaimana telah dijelaskan dalam penjelasannya pandangan mazhab Hanabilah terhadap mashlahat. Namun mazhab Zaidiyah dalam membatasi munasib mursal sebagimana imam Maliki membatasinya yaitu :

a. Mashlahat tersebut harus sesuai dengan maksud-maksud syara', yaitu bukan mashlahat yang gharib (anih/asing).

b. Mashlahat tersebut tidak mulghat, yaitu menurut merka tidak memaksa pemikirannya pada lahirnya, tetapi terdapat nash syara` yang menantangnya yang membuat syar' tidak mengakuinya. Contoh berfatwa mengenai seorang raja yang berjima' pada siang hari bulan Ramadhan, maka kifarat yang diberikan adalan shaumnya, karena memersekakan hamba sahaya lebih mudan dan dapat berbuat cecara berulang-ulang. Fatwa ini adalah munasib yang mulghat yang ditolak oleh syara' Allah telah menetapkan urutkan dalam membayar kifaratnya.

Jadi mazhab Zaidiyah memandang mashlahat mursalah adalah bahagian dari qiyas dengan syarat harus munasib dan mula im yang tidak gharib dan mulgha. Oleh karen itu mashlahat menurut mazham Zaidiyah sama dengan yang dimaksud dengan qiyas ‘am (qiyas umum).

\section{Mazhab Syi ah Imamiyah}

Mazhab Syi ah Imamiyah sudah barang pasti bahagian dari golongan sy`iah. Mereka menolah qiyas, lalu kemudian mereka menolah Istihsan dan Istishlah dengan jalan aulawiyah (mengutamakan). Hal ini disebabkan tafsir dan ijtihad para imam mereka pada posisi nash-nash syari at. Alasan mereka adalah imam meraka ma`shum (terpelihara) dari maksiat, kesalahan dan kelupaan, baik urusan lahir maupun bathin. Eksistensinya imam ma`shum adalah dapat membuat mereka tidak memerlukan qiyas, karena perkataannya adalah hujjah sebagai konsekwensi dari kema`shumannya. Dalam menetapkan hukum tidak perlu ada pertanyaannya 
lagi, kenapa harus begini?. Berdasarkan hal ini qiyas merupakan hal yang batil dan sebuah kebid ahan dalam agama. ${ }^{28}$

Menurut Ali Kasyif al Ghatha menyebutkan bahwa "dalil-dalil syara' terbatas pada Alquran, Sunnah, akal dan Ijma', tidak ada bedanya antara imamiyah dan mazhab-mazhab yang lain. Namum yang berbeda dalam mazhab si ah Imamiyah dalam hal hukum adalam tidak mengamalkan qiyas. Paa imam meraka sudah memiliki sebuah pandangan bahwa "Sesungguhnya bila dalam syari at diterapkan qiyas, maka akan menghancurkan agama”. Larangan ini dalam mazhab syi ah disepakati bila illat nash dalam maqis alaih (tepat sandaran qiyas) adalah musthanbathah (digali mujtahid). Menurut mereka, hal ini berarti tahkkum (mencari hukum sendiri) dalam menetapkan illat pembuat syara`. Namun apabila illat tersebut manshush (ditetapkan syara') maka mereka berbeda pendapat dalam kebolehan menggunakan qiyas dan dapat mengaplikasikan hukum kepada semua perkara yang mengandung illat tersebut. ${ }^{29}$

Menurut Abu Qasim bin Hasan al Jailani al Qumi menjelaskan bahwa mengenai Ijma` mazhab syiah Imamiyah, yang dimaksud dengan mashlahah mursalah adalah menolak kemadharatan dan menarik kemanfaatan untuk agama atau dunia. Kadang-kadang mashlahat itu mu`tabarah (diakui) menuru syara’ meskipun hukum keqath iyannya ditetapkan oleh akal, yaitu mengakui mashlahat yang tidak dicampuri oleh mafsadat. Seperti memeliharakan agama, jiwa, akal, keturunan dan harta. Kadang-kadang mashlahat itu mulghah, seperti kewajiban berpuasa dua bulan berturut-turu sebagai kifarat bagi orang kaya dengan alasan lebih mencegah (sebagaimana penjelasan di belakang). Kadang-kadang mashlahat itu mursalah artinya mashlahat yang tidak didukung oleh syara' dan juga tidak menolak, serta mashlahat tersebut rajih (kiat) tidak dicampuri oleh mafsadat. Sebahagian yang lain menerima mashlahat mursalah.

Bagi yang menolah mashlahat mursalah ini memandang bahwa mashlahat mursalah tidak memiliki dalil yang dapt membenarkannya yang dapat menunjuki kehujjahannya, dan karena pambuar syara` diikuti oleh pembuat syara` lainnya

${ }^{28}$ Lihat: Abu Zahrah, Muhadharah fi Ushul Fiqhi al Ja`fari, hlm.29, 39 dan 40. Lihat juga Mushthafa Zai, Al Mashlahat, hlm. 62

${ }^{29}$ Lihat : Abu Zahrah, al Imam al Sadiq,.. hlm.106 dan 413. 
sebagai sumber pembuat syara' yang kedua. Perdapat yang menolak ini adalam manyoritas dari mazhab ini.

Sementara mereka yang mengakui mashlahah mursalah sebagai hujjah hukum, mengemukakan argumentasinya bahwa jika mashlahat tersebut tidak diperhatikan, maka akan dampak kosongnya peristiwa-peristiwa dari hukum, dan ini adalah bathil sebagaimana telah diketahui tentang hukum perkara yang tidak ada nashnya.

\section{Mazhab Zahiriyah (202)}

Pendapat mazhab zahiriyah mengenai masalah Istihsan dan Istislah adalah sebagaimana mazhab syi ah Imamiyah apabila dilihat secata umum atau dari aspek kesimulan, wlaupun dasar-dasar logika yang digunakan berbeda.

Mazhab Zahiri menolak qiyas sebagaiman implikasinya mereka pun menolak Istihsan dan Istishlah. Mazhab syi ah Imamiyan menolak qiyas, Istihsan dan Istislah atas dasar pemikiran kema`suman imam mereka, sedangkan mazhab Zahiriyah, mereka mamahami leterarur secara tektual terhadap nash-nash. Mereka tidak memperhatikan nilai-nilai akal yang di hadapan nash dalam mengetahui bangunan-bangunannya, illat-illat dan hubungan nash dengan tujuan-tujuan syar`i. Mereka mamandang bahwa azas fiqih adalah tidak ada ta`lilnya (illa-illatnya) terhadap nash-nash syara'

Sebahagian fuqaha melihat bahwa mazhab al Zahiri lahir dai mazhab Syafi i, karena Daud al Zahiri murid dari Syafìi. Namum Daud al Zahiri menolak adanya illat nash dan makna-maknanya. Dalah hal ini, Daud pernah ditanya, mengapa ia berbeda dengan Syafi i dalam masalah qiyas ? daud menjawa: "Saya mengambil dalil-dalil Syafi i dalam menolak Istihsan, kemudian saya menemukan dalam dalil tersebut yang dapat berguna untuk menolak qiyas. ${ }^{30}$

\section{PENUTUP}

Para ulama memilik gagasan yang berbeda dalam memandang al istidhlah/ mashlah mursalah, diantara mereka ada yang menerima dan ada yang menolak, serta ada yang berbeda istilah namun penerapanya sama, dan setelah dikombinasikan ternyata sama.

\footnotetext{
${ }^{30} \mathrm{Abu}$ Zahrah, al Imam al Zaid, faqrah ke- 414.
} 
Diantara mujtahid menduga bahwa setiap hukum yang diistnbathkan adalah sesuai dengan maksud Allah, kadang ternyata menurut mujtahid yang lain belum sesuai dengan keinginan syara'. Maka barang siapa yang berijtihad sesuai dengan kehendak Allah, maka akan mendapat dua pahala. Maka oleh karena itu antara satu mujtahid dengan mujtahid lainnya tidak boleh saling menyalahkan, kalau terjadi hal seperti ini, maka harus kembali kepada sumber aslinya, Alquran dan Sunnah.

Perbedaan pendapat para ulama dan mujtahi dalam masalah furu adalah ramat, sedangkan dalam masalah ushul adalah bala/bencana (niqmah). 


\section{DAFTAR PUSTAKA}

Abu Muhammad bin Abdullah bin Hamid al Salimi, Syams Ushul; tela'ah al syams Syarh al Alfiyah,

Abu Zahrah, Muhadharah fi Ushul Fiqhi al Ja fari,

Al Anshar, Lisan Al Arab , Juz, 9, hlm 279. Taj al Urus, juz.1, hlm. 6066. Al Nihayat fi al Gharib al Atasr, Juz.4.

Al Ghazali, Al Mustashfa

Al Syathibi, Al I`tisham, juz. II, (t.t.), hlm.295.

Al Syathibi, Al Muwafaqat, juz II hlm. 308.

HA.Djazuli, dan Nurol Aen MA, Drs., Ushul Fiqh, (Bandung Gilang Adiiya Press, 1996).

Izzuddin Bin abd al Salam, Qawa id Ahkam fi Mashalih al Anam, juz.II.

Mushthafa Zai, Al Mashlahat.

Mushthafa Zaid, Risalah al Mursalat fi al Tasyri al Islami, ed.I, (Dar Fikri Aabiy, t.th), hlm.40. lihat: Al Juwaini, al Burhan fi Ushul Fiqh, (Dar al Kutb,t.t)

Mustafa Ahmad Al Zarqa', Al Istishlah wa al Mashalih al Mursalah fi al Syari at al Islamiyah wa Ushul Fiqh, Trj. Ade Dedi Rohayana, Hukum Islam dan Perubahan Sosial, (Jakarta: Riora Cipa, 2000). 